Article

\title{
Synthesis, Molecular Docking and Biological Evaluation of Glycyrrhizin Analogs as Anticancer Agents Targeting EGFR
}

\author{
Yong-An Yang ${ }^{1}$, Wen-Jian Tang ${ }^{2, *}$, Xin Zhang ${ }^{1}$, Ji-Wen Yuan ${ }^{1}$, Xin-Hua Liu ${ }^{1,2}$ and \\ Hai-Liang Zhu ${ }^{1, *}$
}

1 State Key Laboratory of Pharmaceutical Biotechnology, Nanjing University, Nanjing 210093, China; E-Mails: yangyan73@163.com (Y.-A.Y.); prczhangxin@163.com (X.Z.); 363718480@163.com (J.-W.Y.); xhliuhx@163.com (X.-H.L.)

2 School of Pharmacy, Anhui Medical University, Hefei 230032, China

* Authors to whom correspondence should be addressed; E-Mails: tangwjster@gmail.com (W.-J.T.); zhuhl@nju.edu.cn (H.-L.Z.); Tel./Fax: +86-551-6516-1115 (W.-J.T.).

Received: 10 April 2014; in revised form: 4 May 2014 / Accepted: 14 May 2014 /

Published: 19 May 2014

\begin{abstract}
Glycyrrhizin (GA) analogs in the form of 3-glucuronides and 18-epimers were synthesized and their anticancer activities were evaluated. Alkaline isomerization of monoglucuronides is reported. In vitro and in vivo studies showed that glycyrrhetinic acid monoglucuronides (GAMGs) displayed higher anticancer activities than those of bisglucuronide GA analogs, while anticancer activity of the $18 \alpha$-epimer was superior to that of the $18 \beta$-epimer. $18 \alpha$-GAMG was firstly nicely bound to epidermal growth factor receptor (EGFR) via six hydrogen bonds and one charge interaction, and the docking calculation proved the correlation between anticancer activities and EGFR inhibitory activities. Highly active $18 \alpha$-GAMG is thus of interest for the further studies as a potential anticancer agent.
\end{abstract}

Keywords: glycyrrhizin; anticancer activity; EGFR; 18-epimer; molecular docking

\section{Introduction}

The epidermal growth factor receptor (EGFR) is a transmembrane glycoprotein that defines a family of tyrosine kinase receptors (TKRs) including ErbB2/HER2, ErbB3/HER3 and ErbB4/HER4 [1,2]. As a cell surface protein that binds to epidermal growth factor, its binding to a ligand induces receptor dimerization and tyrosine autophosphorylation and leads to cell proliferation, of which altered activity has been implicated in the development and growth of many tumors [3]. EGFR is highly expressed in 
adult hepatocytes and the EGFR family plays a central hepatoprotective and pro-regenerative role in the liver [4,5]. Mice lacking EGFR or heparin-binding EGF show delayed regeneration after partial hepatectomy $(\mathrm{PH})$, which demonstrates that EGFR is a critical regulator of hepatocyte proliferation during liver regeneration [6,7]. The treatment of hepatocellular carcinoma (HCC) cells with EGFR-specific tyrosine kinase inhibitors or neutralizing antibodies induces cell cycle arrest and apoptosis and increases chemosensitivity [8,9]. Hence, EGFR has long been an attractive candidate as anticancer drug target. Over the past 30 years, much effort has been directed at developing anticancer agents that can interfere with EGFR activity, such as, monoclonal antibodies and small-molecule inhibitors.

Natural products play a major role in drug discovery, and nearly half of the new drugs introduced into the market over the past two decades are natural products or their derivatives [10]. The roots and rhizomes of licorice (Glycyrrhiza) species have long been used worldwide as a herbal medicine and natural sweetener. Glycyrrhizin (Glycyrrhizic acid, GA, 18 $\beta$-GA), the major bioactive compound in licorice, is developed as a drug with multi-pharmacological effects such as anti-inflammation, antivirus, anti-tumor, and immuno-modulating properties, among others [11-13]. GA has been used in Japan for more than 60 years as a treatment for chronic hepatitis $\mathrm{C}$, thus long-term administration was effective in preventing hepatic cirrhosis and HCC [14-16]. GA exhibits hepatoprotective activity by decreasing serum liver enzyme levels and improving tissue pathology in hepatitis patients, while in vitro studies showed that its anticancer activity is achieved by inhibiting abnormal cell proliferation, tumor formation and growth [17-20].

GA is a conjugate of an $18 \beta$-H-oleanane-type aglycone and two glucuronic acids at the $\mathrm{C}-3$ position, and it could be transformed into $18 \beta$-glycyrrhetinic acid monoglucuronide (18 $\beta$-GAMG) by removing one terminal glucuronic acid [21,22]. Compared to GA, 18 $\beta$-GAMG showed similar (or stronger) pharmacological activities, such as antitumor, antivirus, anti-allergic, and anti-inflammatory

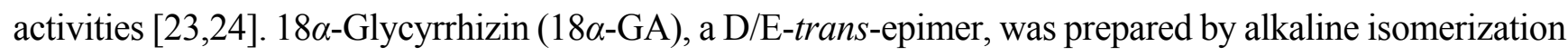
of 18 $\beta$-GA [25]. 18 $\alpha$-GA also showed similar anti-inflammatory and anticancer activity [26,27]. Researches showed that GA analogs are primary hepatocyte mitogens that bind to EGFRs and subsequently stimulate the receptor tyrosine kinase mitogenactivated protein kinase pathway to induce hepatocyte DNA synthesis and proliferation [28]. Herein, we prepared glycyrrhizin analogs (Figure 1) and further evaluated their anticancer activities in vitro and in vivo.

Figure 1. Glycyrrhizin analogs with 3-glucuronides and 18-epimers.

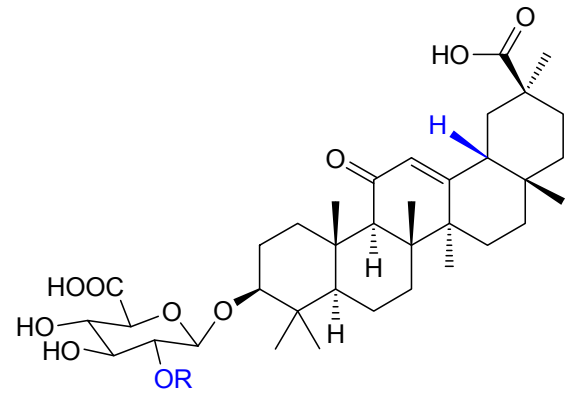

18ק-GAMG: $\mathrm{R}=\mathrm{H}$

18 $\beta$-GA: $\mathrm{R}=$ glucuronide

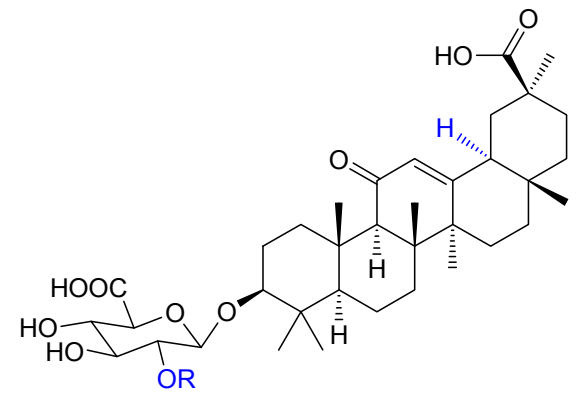

18 $\alpha$-GAMG: $\mathrm{R}=\mathrm{H}$

18 $\alpha$-GA: $\mathrm{R}=$ glucuronide 
Based on the EGFR complex structure (PDB Code 1M17) [29], computer-generated docking molecular models of GA analogs were analyzed using the Discovery Studio 3.5, and we also initiated an effort to leverage molecular modeling in combination with available data to study the effect of structure of glycyrrhizin on anticancer activity.

\section{Results and Discussion}

GA (18 $\beta$-GA) was provided by Jiangsu Tian Sheng Pharmaceutical Co. Ltd., Jiangsu, China. Aspergillus sp Ts-1, a kind of $\beta$-glucuronidase, selectively hydrolyzed the terminal-glucuronyl linkage of $18 \beta$-GA to produce $18 \beta$-GAMG in $54 \%$ yield. $18 \alpha$-GA and $18 \alpha$-GAMG were respectively synthesized in yields of $63 \%$ and $71 \%$ after recrystallization from $18 \beta$-GA and $18 \beta$-GAMG by alkaline isomerization. The isomerization reaction was monitored by ${ }^{13} \mathrm{C}-\mathrm{NMR}$ spectroscopy, and the structure of $18 \alpha$-GAMG was elucidated by comparison with ${ }^{1} \mathrm{H}-\mathrm{NMR}$ and ${ }^{13} \mathrm{C}-\mathrm{NMR}$ data of $18 \beta$-GAMG [30] (see Supplementary Information).

Anti-proliferative activities of glycyrrhizin analogs and erlotinib against the HepG2 (hepatocellular carcinoma), HeLa (cervix of uterus adenocarcinoma) and A549 (lung carcinoma), were evaluated by CCK8 dye assays. The results, summarized in Table 1, revealed that four glycyrrhizin analogs exhibited significant antitumor activities. Two monoglucuronide compounds, 18 $\alpha$-GAMG and $18 \beta$-GAMG, exhibited more significant antitumor activities than those with bisglucuronide GAs, while the antitumor activity of the $18 \alpha$-epimer was superior to that of $18 \beta$-epimer for identical cell lines. Among the four analogs, $18 \alpha$-GAMG displayed the most potent activity, with $\mathrm{IC}_{50}$ values of $6.67,7.43$ and $15.76 \mu \mathrm{M}$ against HepG2, Hela and A549, respectively.

Table 1. In vitro anticancer activities $\left(\mathrm{IC}_{50}, \mu \mathrm{M}\right)$ of title compounds against human tumor cell lines.

\begin{tabular}{cccc}
\hline \multirow{2}{*}{ Compd. } & \multicolumn{3}{c}{$\mathbf{I C}_{\mathbf{5 0}},(\boldsymbol{\mu M})^{\mathbf{a}}$} \\
\cline { 2 - 4 } & $\mathbf{H e p G 2}^{\mathbf{b}}$ & $\mathbf{H e L a}^{\mathbf{b}}$ & $\mathbf{A 5 4 9}^{\mathbf{b}}$ \\
\hline 18 $\alpha$-GAMG & 6.67 & 7.43 & 15.76 \\
18 $\beta$-GAMG & 33.60 & 8.39 & 21.55 \\
18 $\alpha$-GA & 54.24 & 15.13 & 41.57 \\
18 $\beta$-GA & 63.59 & 18.93 & 51.92 \\
Erlotinib & 0.12 & 0.20 & 0.13 \\
\hline
\end{tabular}

a Antiproliferation activity was measured using the CCK-8 assay. Values are the average of three independent experiments run in triplicate. Variation was generally $5 \%-10 \%$; ${ }^{\mathbf{b}}$ Cancer cells kindly supplied by State Key Laboratory of Pharmaceutical Biotechnology, Nanjing University.

To generate data concerning the broad spectrum potential of these compounds in Table 2 , the $\mathrm{IC}_{50}$ values of synthesized compounds against EGFR enzymes are summarized in Table 2. Reference data for erlotinib had also been included for comparison with the compounds reported in this study. For the majority of the compounds, we found that compound $18 \alpha-\mathrm{GAMG}$, with an $\mathrm{IC}_{50}$ of $0.028 \mu \mathrm{M}$, was a better inhibitor than the positive control erlotinib with an $\mathrm{IC}_{50}$ of $0.030 \mu \mathrm{M}$, suggesting that, at least in part, inhibition of proliferation of the these lines may be the result of EGFR inhibition. 
Table 2. Data of the in vitro EGFR ( $\left.\mathrm{IC}_{50}, \mu \mathrm{M}\right)$ enzyme inhibition assay of the synthesized compounds.

\begin{tabular}{cccc}
\hline Compd. & EGFR $\left(\mathbf{I C}_{\mathbf{5 0}}, \boldsymbol{\mu M}\right)^{\mathbf{a}}$ & Compd. & EGFR $\left(\mathbf{I C}_{\mathbf{5 0}}, \boldsymbol{\mu M}\right)^{\mathbf{a}}$ \\
\hline $18 \alpha$-GAMG & 0.028 & $18 \beta$-GA & 0.092 \\
$18 \beta$-GAMG & 0.069 & Erlotinib & 0.030 \\
18 $\alpha$-GA & 0.081 & & \\
\hline
\end{tabular}

${ }^{a}$ Minimum cytotoxic concentration required to cause a microscopically detectable alteration of normal cell morphology.

In order to gain more understanding of the structure-activity relationships observed at the EGFR, molecular docking of the most potent inhibitor $18 \alpha$-GAMG and EGFR was performed on the binding model based on the EGFR complex structure (PDB Code 1M17) using the Discovery Studio 3.5 software [29]. The docking calculation of the analogs was depicted in Table 3, and as shown in Table 3, all analogs had nice binding affinity to EGFR and four analogs' -EDOCKER_ INTERACTION_ ENERGY had the same trend as the anti-proliferative activities, which further proved the correlation between the anti-proliferative activities and EGFR inhibitory activities of the analogs.

Table 3. -EDOCKER_INTERACTION_ENERGY of title compounds and 1M17.

\begin{tabular}{cc}
\hline Compd. & -EDOCKER_INTERACTION_ENERG $\boldsymbol{\Delta} \mathbf{G}(\mathbf{k c a l} / \mathbf{m o l})$ \\
\hline $18 \alpha-\mathrm{GAMG}$ & 72.0274 \\
$18 \beta$-GAMG & 66.9106 \\
$18 \alpha-\mathrm{GA}$ & 58.7009 \\
$18 \beta$-GA & 58.6731 \\
Erlotinib & 44.3732 \\
\hline
\end{tabular}

In the result of molecular docking, 18 $\alpha$-GAMG showed maximum -EDOCKER INTERACTION_ENERGY, which suggested it was mostly easy to bind to EGFR. The 2D and 3D binding models of $18 \alpha$-GAMG with EGFR are depicted in Figure 2. The amino acid residues which had interactions with EGFR as well as bond lengths were labeled. In the binding models, 18 $\alpha$-GAMG was nicely bound to EGFR via six hydrogen bonds with ASP831 (angle $=120.49^{\circ}$, distance $=2.14 \AA$ ), GLU738 $\left(\right.$ angle $=142.28^{\circ}$, distance $\left.=2.2 \AA\right)$, THR766 (three bonds: angle $=140.28^{\circ}$, distance $=2.1 \AA$; angle $=117.6^{\circ}$, distance $=2.3 \AA$; angle $=152.94^{\circ}$, distance $\left.=2.0 \AA\right)$ and LYS721 $\left(\right.$ angle $=179.02^{\circ}$, distance $=1.7 \AA$ ). In addition, compound $18 \alpha$-GAMG was also nicely bound to EGFR via one charge interaction. The end group of LYS692 formed one charge interaction with a carboxyl which strengthened the binding affinity, leading to the increased anticancer activities of $18 \alpha$-GAMG. Besides, the hydrogens of LYS692, LYS692 and PRO770 formed three hydrogen bonds interaction with the amino group nitrogen atom of $18 \beta$-GAMG (angle $\mathrm{H}-\mathrm{N}_{\mathrm{LYS} 692} \mathrm{O} 35=151.7^{\circ}$, distance $=1.98 \AA$, angle $\mathrm{H}$ LYS692 $\mathrm{O} 36=123.6^{\circ}$, distance $=2.47 \AA$, angle $\mathrm{H} 96 \mathrm{O}_{\mathrm{PRO} 70}=113.4^{\circ}$, distance $=2.22 \AA$ ). Furthermore, compound $18 \beta$-GAMG was also nicely bound to EGFR via three charge interactions. The end group of LYS692, LYS704 and LYS721 respectively formed three charge interactions with two carboxyls. These molecular docking results, along with the biological assay data, suggest that compound $18 \alpha-G A M G$ possesses higher anticancer activity than $18 \beta$-GAMG, which will help us carry out structure optimization based on computer-aided design. 
Recently, 18 $\beta$-GA has been recognized as a hepatoprotective high-mobility group protein 1 (HMGB1) inhibitor, which binds directly to both HMG boxes in HMGB1 and attenuates HMGB1-induced hepatocyte apoptosis, thus leading to induce hepatocyte DNA synthesis and proliferation [31,32]. As it is, 18 $\beta$-GA induced hepatocyte proliferation, while we got the opposite results in cancer cells. The binding moiety of $18 \alpha$-GAMG with EGFR was mainly the glucuronide unit, but GA could inhibit HMGB1 by binding of its triterpene ring directly to the two HMG boxes. These results showed that the protein targets and molecular pathways affected by GA may be complicated and heterogeneous.

Figure 2. (a) 2D molecular docking modeling of 18 $\alpha$-GAMG with 1M17. (b) 3D model of the interaction between $18 \alpha$-GAMG and $1 \mathrm{M} 17$ site. (c) 2D molecular docking modeling of $18 \beta$-GAMG with $1 \mathrm{M} 17$. (d) $3 \mathrm{D}$ model of the interaction between $18 \beta$-GAMG and $1 \mathrm{M} 17$ site.
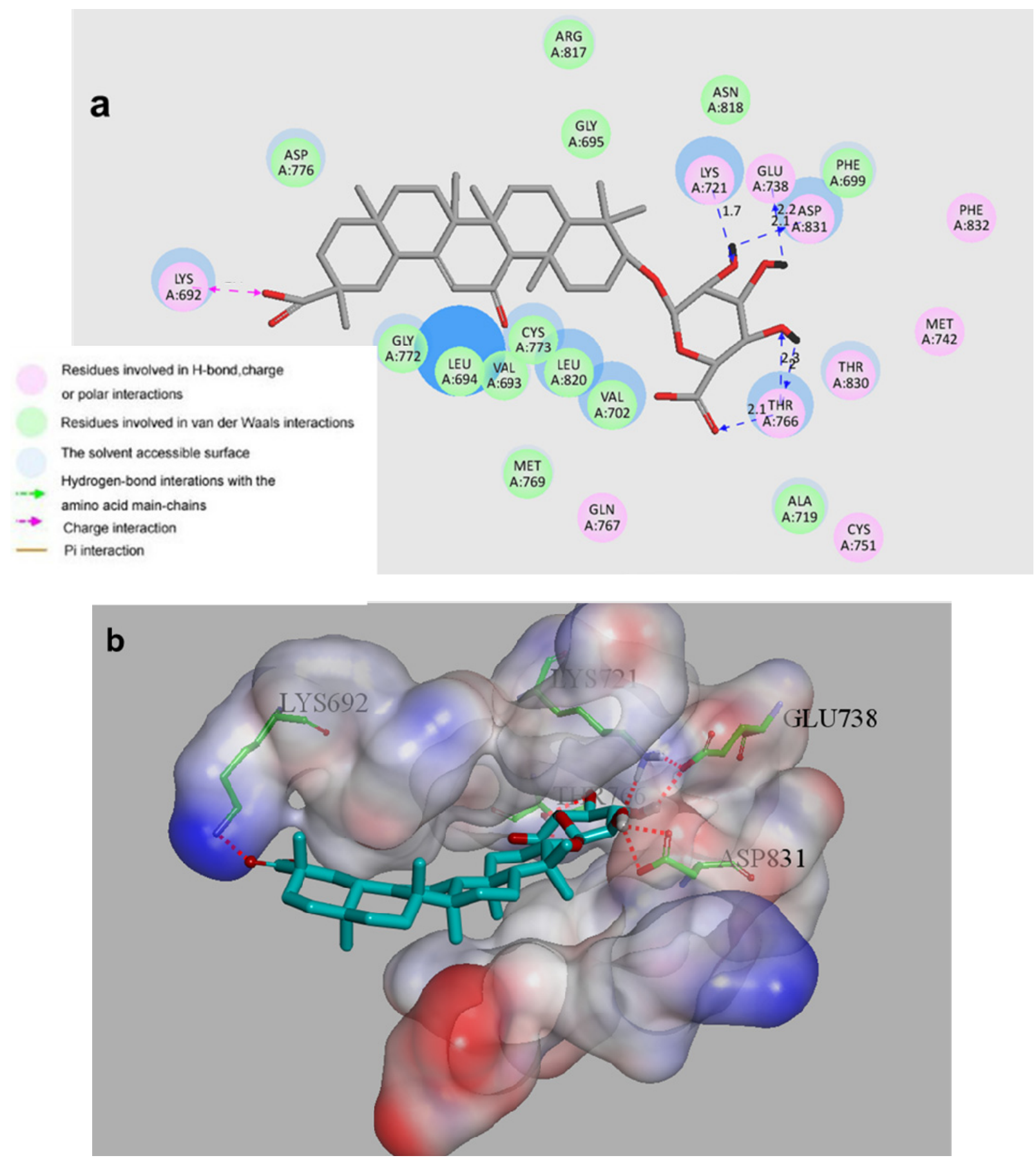
Figure 2. Cont.

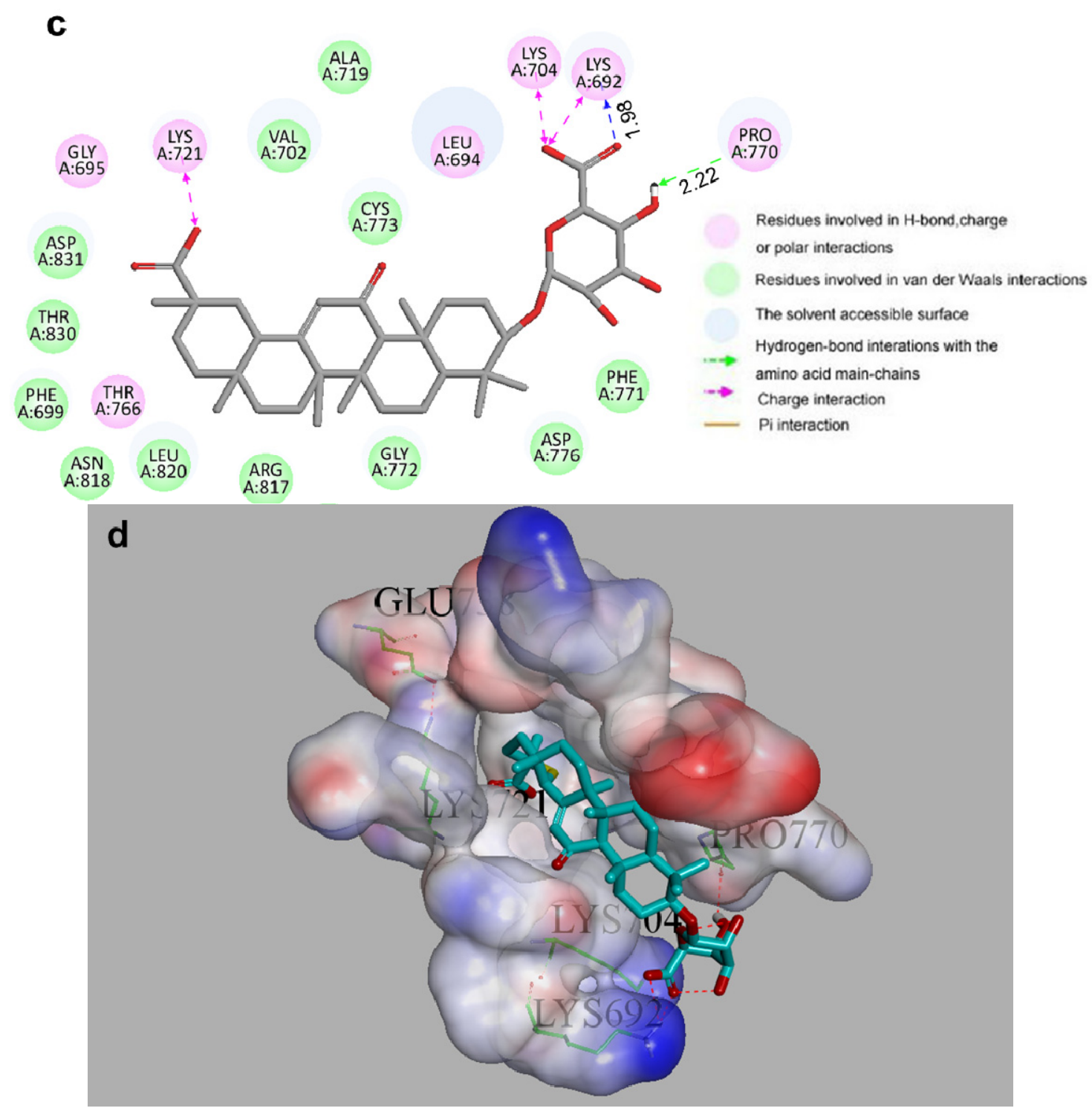

To further verify the inhibitory effect of glycyrrhizin analogs on the growth of tumor cells in vivo, sarcoma cells S180, hepatoma cells HepG2 and Ehrlich ascites cells EAC were selected to evaluate in vivo antitumor effects. The inhibitory effects of glycyrrhizin analogs on the growth of the transplanted S180 or HepG2 carcinoma are presented in Table 4 and Figure 3. The results revealed that glycyrrhizin analogs significantly decreased the tumor weights of S180 and HepG2 tumor-bearing mice. The inhibitory rates of GAMGs were higher than those of GAs, while the inhibitory rate of the $18 \alpha$-epimer was higher than that of corresponding $18 \beta$-epimer. The most potent activity was showed by 18 $\alpha$-GAMG with inhibitory rates $39.8 \%$ and $49.7 \%$ for S180 and HepG2 tumor-bearing mice at the dosage of $60 \mathrm{mg} / \mathrm{kg} /$ day, respectively.

EAC tumor-bearing mice were observed for mean survival time. The effect of glycyrrhizin analogs on percentage increases in life span was calculated on the basis of mortality of the experimental mice. Survival response of untreated EAC-bearing mice died within 16.4 days (Table 5). A similar phenomenon was observed: mice administered monoglucuronide and $18 \alpha$-epimer displayed longer survival times. The $18 \alpha$-GAMG group was observed to enhance the survival rate to $45.4 \%$. 
Based on in vitro and in vivo experiments, followed by molecular docking, we here demonstrated that the protein target Epidermal Growth Factor Receptor (EGFR) was also sensitive to four glycyrrhizin analogs in three types of carcinoma cells, indicative of their potential anticancer activity as the EGFR inhibitors. The result was significant and intriguing, but further studies needs to be provided to systematically elucidate the direct correlation between the glycyrrhizin analogs and the EGFR target, which would reveal the new mechanism of glycyrrhizin action.

Table 4. Antitumor effects of glycyrrhizin analogs against tumor growth on the S180 and HepG2 xenograft mice. ${ }^{\text {a }}$

\begin{tabular}{|c|c|c|c|c|c|c|}
\hline \multirow{2}{*}{ Models } & \multirow{2}{*}{ Groups } & \multirow{2}{*}{$\begin{array}{c}\text { Animal number } \\
\text { (End, n) }\end{array}$} & \multicolumn{2}{|c|}{ Body weight (g) } & \multirow{2}{*}{$\begin{array}{c}\text { Tumor weight } \\
\text { (g) }\end{array}$} & \multirow{2}{*}{$\begin{array}{c}\text { Inhibition rate } \\
(\%)\end{array}$} \\
\hline & & & Beginning & End & & \\
\hline \multirow{5}{*}{ S180 } & Control & 10 & $19.80 \pm 1.32$ & $23.97 \pm 2.23$ & $1.91 \pm 0.29$ & \\
\hline & $18 \alpha-\mathrm{GAMG}$ & 9 & $19.40 \pm 1.07$ & $25.25 \pm 1.80$ & $1.15 \pm 0.50 * *$ & 39.8 \\
\hline & $18 \beta$-GAMG & 10 & $19.80 \pm 1.39$ & $25.02 \pm 2.58$ & $1.25 \pm 0.19 * *$ & 34.6 \\
\hline & $18 \alpha-\mathrm{GA}$ & 10 & $20.00 \pm 1.49$ & $25.20 \pm 1.11$ & $1.29 \pm 0.47 * *$ & 32.5 \\
\hline & $18 \beta-\mathrm{GA}$ & 9 & $19.70 \pm 1.25$ & $24.48 \pm 2.37$ & $1.33 \pm 0.67 * *$ & 30.4 \\
\hline \multirow{5}{*}{ HepG2 } & Control & 10 & $19.4 \pm 1.35$ & $25.05 \pm 1.89$ & $1.95 \pm 0.22$ & \\
\hline & $18 \alpha-\mathrm{GAMG}$ & 10 & $19.6 \pm 1.51$ & $27.02 \pm 2.10$ & $0.98 \pm 0.43 * *$ & 49.7 \\
\hline & $18 \beta-\mathrm{GAMG}$ & 10 & $19.00 \pm 0.94$ & $27.8 \pm 1.57$ & $1.20 \pm 0.35 * *$ & 38.4 \\
\hline & $18 \alpha-\mathrm{GA}$ & 10 & $20.1 \pm 1.45$ & $26.08 \pm 1.26$ & $1.22 \pm 0.46 * *$ & 37.4 \\
\hline & $18 \beta-\mathrm{GA}$ & 10 & $19.4 \pm 1.08$ & $26.94 \pm 2.05$ & $1.26 \pm 0.65 * *$ & 35.4 \\
\hline
\end{tabular}

a Mice were inoculated with S180 or HepG2 subcutaneously into the right front armpit and randomly divided into five test groups. The mice were daily treated by $18 \alpha$-GAMG, $18 \beta$-GAMG, $18 \alpha$-GA, 18 $\beta$-GA $(60 \mathrm{mg} / \mathrm{kg} /$ day), or normal saline (NS, $10 \mathrm{~mL} / \mathrm{kg}$ ) by oral gavage for ten consecutive days. Data were analyzed using SPSS11.0. Significant difference between each treatment and the control are shown as $P<0.05(*)$ and $P<0.01(* *)$.

Figure 3. Solid tumors from $\mathrm{S} 180$ (above) and HepG2 (below) tumor-bearing mice. $\mathrm{A}$ : 18 $\alpha$-GAMG; B: $18 \beta$-GAMG; C: $18 \alpha-G A ; D: 18 \beta-G A ;$ M: Normal saline.

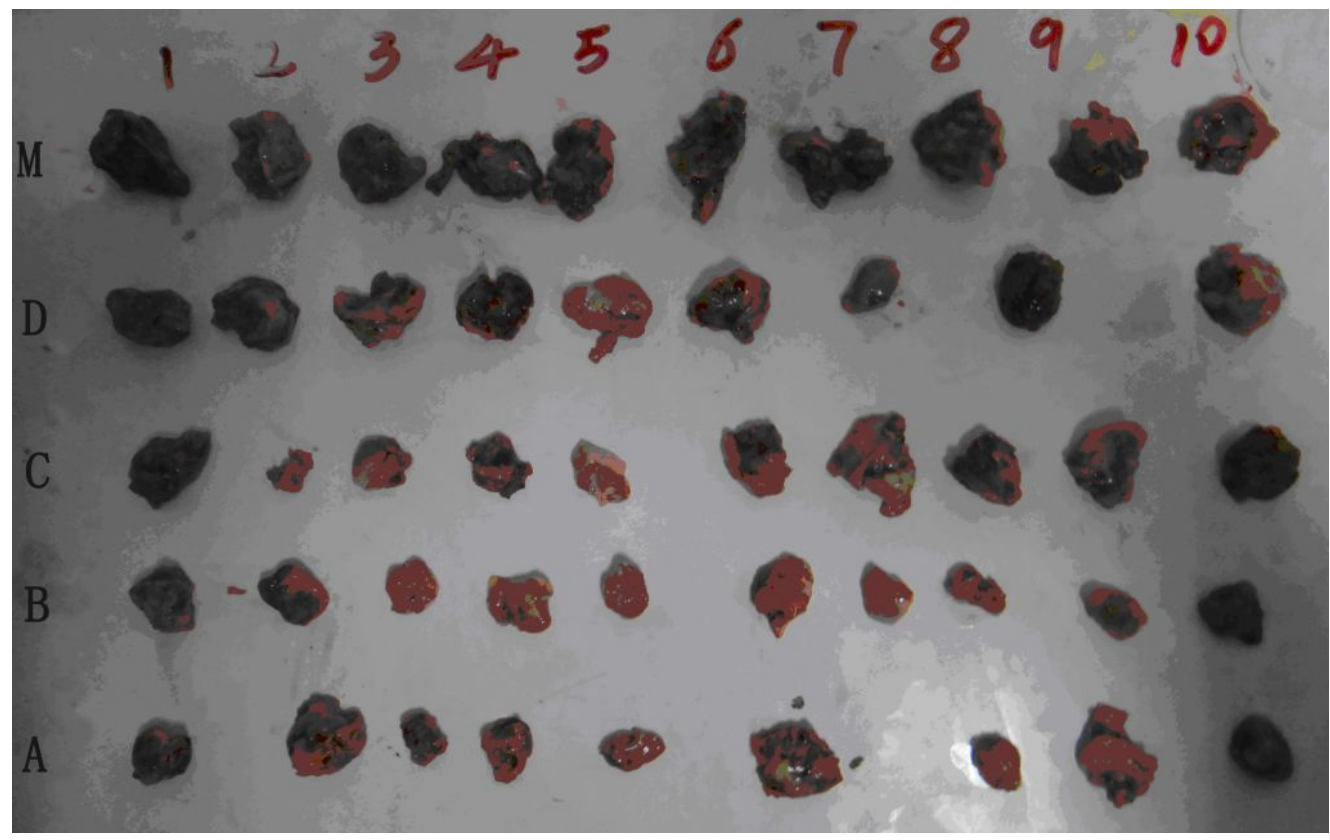


Figure 3. Cont.

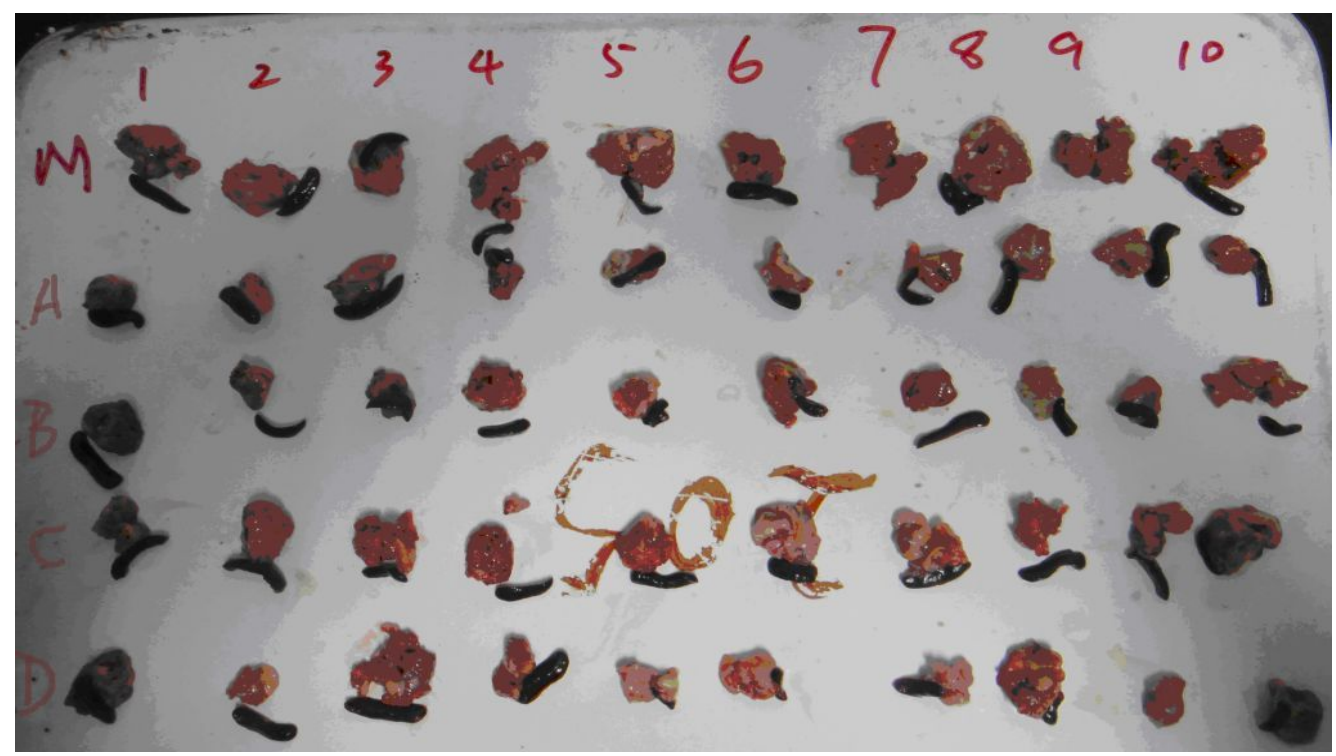

Table 5. Effects of glycyrrhizin analogs against the survival of EAC-bearing mice.

\begin{tabular}{ccccc}
\hline Groups & Animal number (n) & Body weight (g) & Survival time $^{\text {a }}(\mathbf{d})$ & Survival rate (\%) $^{(\%)}$ \\
\hline Control & 10 & $19.0 \pm 1.25$ & $16.40 \pm 2.07$ & \\
$18 \alpha-G A M G$ & 10 & $19.5 \pm 1.27$ & $23.85 \pm 5.41^{*}$ & 45.4 \\
$18 \beta$-GAMG & 10 & $19.0 \pm 0.82$ & $21.05 \pm 4.65^{*}$ & 28.4 \\
$18 \alpha-G A$ & 10 & $19.4 \pm 0.97$ & $19.75 \pm 3.08^{*}$ & 20.4 \\
$18 \beta$-GA & 10 & $19.4 \pm 1.27$ & $19.40 \pm 3.77^{*}$ & 18.3 \\
\hline \multicolumn{5}{c}{ a Time denoted by number of days. $P<0.05(*)$}
\end{tabular}

\section{Experimental Section}

\subsection{Synthesis of Glycyrrhizin Analogs}

\subsubsection{General Methods}

Aspergillus sp. Ts-1 was isolated from soil collected in Kashi of the Xinjiang Uygur Autonomous Region (China) and selectively hydrolyzed the terminal-glucuronyl linkage of $18 \beta$-GA to yield glycyrrhetic acid 3-O-mono- $\beta$-D-glucuronide (18 $\beta$-GAMG). Its subculture and $18 \beta$-GA were provided by Jiangsu Tian Sheng Pharmaceutical Co. Ltd. (Nanjing, China). All materials were obtained from commercial suppliers, were of analytical reagent grade and used without further purification. Melting points were uncorrected. Silica gel (200-300 mesh, Huanghai, Qingdao, China). TLC: pre-coated silica gel $F_{254}$ plates. Optical rotations: polar 3002 polarimeter. NMR spectra: Bruker $A V$ NMR spectrometer $\left({ }^{1} \mathrm{H}: 500\right.$ or 300 and ${ }^{13} \mathrm{C}: 125$ or $\left.75 \mathrm{MHz}\right)$, the residual solvent peaks used as an internal standard, $J$ in $\mathrm{Hz}$. TOF- HR MS: Agilent 1260-6221 TOF LC/MS.

\subsubsection{Preparation of $18 \beta$-GAMG from $18 \beta$-GA via Biotransformation}

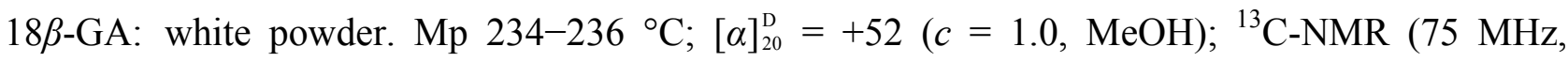
DMSO- $d_{6}$ ): Table S1. TOF-HRMS: $m / z[\mathrm{M}+\mathrm{Na}]^{+}$calcd for $\mathrm{C}_{42} \mathrm{H}_{62} \mathrm{NaO}_{16}$ : 845.3930; found: 845.3935. 
Aspergillus sp. Ts-1 on glucose yeast agar slant was inoculated into a $250 \mathrm{~mL}$ Erlenmeyer flask containing $100 \mathrm{~mL}$ of seed medium consisting of $1.0 \mathrm{~g}$ glucose, $0.2 \mathrm{~g}$ yeast, $1.0 \mathrm{~g}$ agar, $0.1 \mathrm{~g} \mathrm{KH}_{2} \mathrm{PO}_{4}$ and $0.025 \mathrm{~g} \mathrm{MgSO}_{4}$ in distilled water ( $\mathrm{pH} \mathrm{7.0)}$ ). The culture media were sterilized at $121^{\circ} \mathrm{C}$ for $20 \mathrm{~min}$ and the fermentation was carried out at $30{ }^{\circ} \mathrm{C}$ on a rotary shaker at $200 \mathrm{rpm}$. After $24 \mathrm{~h}$ of inoculation, $30 \mathrm{~mL}$ sterilized medium was inoculated into a $1,000 \mathrm{~mL}$ Erlenmeyer flask containing $300 \mathrm{~mL}$ pre-culture sample consisting of $15 \mathrm{~g} \mathrm{GA}, 0.30 \mathrm{~g} \mathrm{KH}_{2} \mathrm{PO}_{4}, 3.0 \mathrm{~g}$ urea and $0.24 \mathrm{~g} \mathrm{MgSO}_{4}$ in distilled water and the $\mathrm{pH}$ value was adjusted to 6.0 . The culture media were sterilized at $121{ }^{\circ} \mathrm{C}$ for $20 \mathrm{~min}$ and the fermentation was carried out at $30{ }^{\circ} \mathrm{C}$ on a rotary shaker at $250 \mathrm{rpm}$.

After $72 \mathrm{~h}$ of inoculation, the culture solution was filtered and the filtrate was extracted with ethyl acetate. The extract was concentrated under the reduced pressure. The residue $(14.5 \mathrm{~g})$ was applied to a silica gel column $(800 \mathrm{~g}, 5.0 \times 100 \mathrm{~cm})$ and eluted with $\mathrm{CHCl}_{3}-\mathrm{MeOH}$ in a gradient manner from 100:1 to 1:1. By TLC analysis, fractions I-IX was obtained. Fractions VI-VIII was concentrated in vacuo and recrystallization from aqueous $\mathrm{MeOH}$ to give 18 $\beta$-GAMG (6.35 g, 54\% yield) as a white crystalline powder. Mp 237-239 ${ }^{\circ} \mathrm{C}$; $[\alpha]_{20}^{\mathrm{D}}=+91(c=1.0, \mathrm{MeOH}) ;{ }^{1} \mathrm{H}-\mathrm{NMR}\left(500 \mathrm{MHz}, \mathrm{DMSO}-d_{6}\right) \delta(\mathrm{ppm})$ : $0.76\left(\mathrm{~s}, 3 \mathrm{H}, 24-\mathrm{CH}_{3}\right), 0.77\left(\mathrm{~s}, 3 \mathrm{H}, 28-\mathrm{CH}_{3}\right), 0.99\left(\mathrm{~s}, 3 \mathrm{H}, 23-\mathrm{CH}_{3}\right), 1.06\left(\mathrm{~s}, 2 \times 3 \mathrm{H}, 25-\mathrm{CH}_{3}, 26-\mathrm{CH}_{3}\right), 1.10$ (s, 3H, 29- $\left.\mathrm{CH}_{3}\right), 1.34\left(\mathrm{~s}, 3 \mathrm{H}, 27-\mathrm{CH}_{3}\right), 2.34(\mathrm{~s}, 1 \mathrm{H}, 9-\mathrm{H}), 3.01\left(\mathrm{~m}, 1 \mathrm{H}, 4{ }^{\prime}-\mathrm{H}\right), 3.08\left(\mathrm{dd}, 1 \mathrm{H}, J_{1}=4.8 \mathrm{~Hz}\right.$, $\left.J_{2}=11.2 \mathrm{~Hz}, 3-\mathrm{H}\right), 3.15\left(\mathrm{t}, 1 \mathrm{H}, J=9.0 \mathrm{~Hz}, 3^{\prime}-\mathrm{H}\right), 3.30$ (m, 1H, overlapped, 2'-H), 3.58 (d, 1H, $J=9.7 \mathrm{~Hz}$, $\left.5^{\prime}-\mathrm{H}\right), 4.25$ (d, 1H, $J=7.8 \mathrm{~Hz}, 1$ '-H), 5.40 (s, 1H, 12-H); ${ }^{13} \mathrm{C}-\mathrm{NMR}$ (125 MHz, DMSO-d $)_{6}$ : Table S1. TOF-HRMS: $m / z$ [M $+\mathrm{Na}]^{+}$calcd for $\mathrm{C}_{36} \mathrm{H}_{54} \mathrm{NaO}_{10}$ : 669.3609; found: 669.3608 .

\subsubsection{General Procedure of Alkaline Isomerization of the $18 \beta$-isomer to the $18 \alpha$-isomer}

A solution of $18 \beta$-isomer $(6.0 \mathrm{mmol})$ in $5.0 \mathrm{M} \mathrm{NaOH}$ solution $(100 \mathrm{~mL})$ was heated and stirred for $12 \mathrm{~h}$ at $90{ }^{\circ} \mathrm{C}$. After the reaction mixture was cooled to $<5{ }^{\circ} \mathrm{C}$, the $\mathrm{pH}$ was adjusted to 2.5 with concentrated $\mathrm{HCl}$. After $12 \mathrm{~h}$, the mixture was filtrated, washed with water, dried. The product (18 $\alpha$-isomer) was obtained by crystallization from ethanol/EtOAc. (Scheme S1 and Figure S1). 18 $\alpha$-GA: According to the above procedure, diammonium $18 \alpha$-GA (3.17 g, 63\% yield) was obtained from $18 \beta$-GA $(5.00 \mathrm{~g})$ as a white crystalline powder. $\mathrm{Mp} 211-216{ }^{\circ} \mathrm{C} ;[\alpha]_{20}^{\mathrm{D}}=+20(c=1.0, \mathrm{MeOH})$; ${ }^{1} \mathrm{H}-\mathrm{NMR}\left(300 \mathrm{MHz}, \mathrm{DMSO}-d_{6}\right) \delta(\mathrm{ppm}): 0.65$ (s, 3H, 28-CH$), 0.73\left(\mathrm{~s}, 3 \mathrm{H}, 24-\mathrm{CH}_{3}\right), 0.95\left(\mathrm{~s}, 3 \mathrm{H}, 23-\mathrm{CH}_{3}\right)$, $1.04\left(\mathrm{~s}, 3 \mathrm{H}, 26-\mathrm{CH}_{3}\right), 1.10\left(\mathrm{~s}, 3 \mathrm{H}, 25-\mathrm{CH}_{3}\right), 1.16\left(\mathrm{~s}, 3 \mathrm{H}, 29-\mathrm{CH}_{3}\right), 1.33\left(\mathrm{~s}, 3 \mathrm{H}, 27-\mathrm{CH}_{3}\right), 4.31(\mathrm{~d}, 1 \mathrm{H}$, $\left.J=7.3 \mathrm{~Hz}, 1^{\prime}-\mathrm{H}\right), 4.49$ (d, 1H, $\left.J=7.6 \mathrm{~Hz}, 1 "-\mathrm{H}\right), 5.33$ (s, 1H, 12-H); ${ }^{13} \mathrm{C}-\mathrm{NMR}$ (75 MHz, DMSO- $\left.d_{6}\right)$ : Table S1. TOF-HRMS: $m / z[\mathrm{M}+\mathrm{Na}]^{+}$calcd for $\mathrm{C}_{42} \mathrm{H}_{62} \mathrm{NaO}_{16}$ : 845.3930; found: 845.3938.

18 $\alpha$-GAMG: $18 \alpha$-GAMG (2.83 g, 71\% yield) was obtained from 18 -GAMG (4.00 g) as a white crystalline powder. Mp 229-231 ${ }^{\circ} \mathrm{C} ;[\alpha]_{20}^{\mathrm{D}}=+24(c=1.0, \mathrm{MeOH}) ;{ }^{1} \mathrm{H}-\mathrm{NMR}\left(300 \mathrm{MHz}, \mathrm{DMSO}-d_{6}\right)$ $\delta$ (ppm): $0.65\left(\mathrm{~s}, 3 \mathrm{H}, 28-\mathrm{CH}_{3}\right), 0.77\left(\mathrm{~s}, 3 \mathrm{H}, 24-\mathrm{CH}_{3}\right), 0.92\left(\mathrm{~s}, 3 \mathrm{H}, 23-\mathrm{CH}_{3}\right), 0.98\left(\mathrm{~s}, 3 \mathrm{H}, 25-\mathrm{CH}_{3}\right), 1.04$ (s, 3H, 26- $\left.\mathrm{CH}_{3}\right), 1.16$ (s, 3H, 29- $\left.\mathrm{CH}_{3}\right), 1.33$ (s, 3H, 27- $\mathrm{CH}_{3}$ ), 2.27 (overlapped, 9-H), 3.01 (t, 1H, J = 8.4 Hz, $\left.4^{\prime}-\mathrm{H}\right), 3.07$ (dd, $\left.1 \mathrm{H}, J_{1}=6.5 \mathrm{~Hz}, J_{2}=9.7 \mathrm{~Hz}, 3-\mathrm{H}\right), 3.15$ (t, $\left.1 \mathrm{H}, J=9.0 \mathrm{~Hz}, 3^{\prime}-\mathrm{H}\right), 3.30$ (t, 1H, $J=9.8 \mathrm{~Hz}$, $\left.2^{\prime}-\mathrm{H}\right), 3.58$ (d, 1H, $\left.J=9.7 \mathrm{~Hz}, 5^{\prime}-\mathrm{H}\right), 4.24$ (d, 1H, $\left.J=7.8 \mathrm{~Hz}, 1^{\prime}-\mathrm{H}\right), 5.33$ (s, 1H, 12-H); ${ }^{13} \mathrm{C}-\mathrm{NMR}$ (75 MHz, DMSO- $d_{6}$ ): Table S1. TOF-HRMS: $m / z[\mathrm{M}+\mathrm{Na}]^{+}$calcd for $\mathrm{C}_{36} \mathrm{H}_{54} \mathrm{NaO}_{10}$ : 669.3609; found: 669.3600 . 


\subsection{Biological Assay of in Vitro Anticancer Activities}

CCK8 is much more convenient and helpful than MTT for analyzing cell proliferation, because it can be reduced to soluble formazan by dehydrogenase in mitochondria and has little toxicity to cells. Cell proliferation was determined using CCK8 dye (BeyotimeInst Biotech, Shanghai, China) according to manufacturer's instructions. Briefly, $1-5 \times 10^{3}$ cells per well were seeded in a 96-well plate, grown at $37^{\circ} \mathrm{C}$ for $12 \mathrm{~h}$, Subsequently, cells were treated with compounds at increasing concentrations in the presence of $10 \%$ FBS for 24 or $48 \mathrm{~h}$. After $10 \mu \mathrm{L} \mathrm{CCK} 8$ dye was added to each well, cells were incubated at $37{ }^{\circ} \mathrm{C}$ for $1-2 \mathrm{~h}$ and Plates were read in a Victor-V multilabel counter (Perkin-Elmer, Waltham, MA, USA) using the default europium detection protocol. Percent inhibition or $\mathrm{IC}_{50}$ values of compounds were calculated by comparison with DMSO-treated control wells.

\subsection{General Procedure for Preparation, Purification of EGFR, and Inhibitory Assay}

A $1.6 \mathrm{~kb}$ cDNA encoded for the EGFR cytoplasmic domain (EGFR-CD, amino acids 645-1186) were cloned into baculoviral expression vectors pBlueBacHis2B and pFASTBacHTc (Huakang Company, Changsha, China), separately. A sequence that encodes (His) 6 was located at the $5^{\prime}$ upstream to the EGFR sequences. Sf-9 cells were infected for 3 days for protein expression. Sf-9 cell pellets were solubilized at $0{ }^{\circ} \mathrm{C}$ in a buffer at $\mathrm{pH} 7.4$ containing $50 \mathrm{mM}$ HEPES, $10 \mathrm{mM} \mathrm{NaCl}, 1 \%$ Triton, $10 \mu \mathrm{M}$ ammonium molybdate, $100 \mu \mathrm{M}$ sodium vanadate, $10 \mu \mathrm{g} / \mathrm{mL}$ aprotinin, $10 \mu \mathrm{g} / \mathrm{mL}$ leupeptin, $10 \mu \mathrm{g} / \mathrm{mL}$ pepstatin, and $16 \mu \mathrm{g} / \mathrm{mL}$ benzamidine $\mathrm{HCl}$ for $20 \mathrm{~min}$ followed by $20 \mathrm{~min}$ centrifugation. Crude extract supernatant was passed through an equilibrated Ni-NTA superflow packed column and washed with $10 \mathrm{mM}$ and then $100 \mathrm{mM}$ imidazole to remove nonspecifically bound material. Histidine tagged proteins were eluted with 250 and $500 \mathrm{mM}$ imidazole and dialyzed against $50 \mathrm{mM} \mathrm{NaCl}, 20 \mathrm{mM} \mathrm{HEPES,} \mathrm{10 \%}$ glycerol, and $1 \mu \mathrm{g} / \mathrm{mL}$ each of aprotinin, leupeptin and pepstatin for $2 \mathrm{~h}$. The entire purification procedure was performed at $4{ }^{\circ} \mathrm{C}$ or on ice [29].

EGFR kinase assays were set up to assess the level of autophosphorylation based on DELFIA/Time-Resolved Fluorometry. All compounds were dissolved in 100\% DMSO and diluted to the appropriate concentrations with $25 \mathrm{mM}$ HEPES at $\mathrm{pH}$ 7.4. In each well, $10 \mu \mathrm{L}$ compound was incubated with $10 \mu \mathrm{L}$ (5 ng for EGFR) recombinant enzyme (1:80 dilution in 100 mM HEPES) for $10 \mathrm{~min}$ at room temperature. Then, $10 \mu \mathrm{L}$ of $5 \mathrm{mM}$ buffer (containing $20 \mathrm{mM} \mathrm{HEPES,} 2 \mathrm{mM} \mathrm{MnCl}_{2}$, $100 \mu \mathrm{M} \mathrm{Na} \mathrm{VO}_{4}$ and $1 \mathrm{mM}$ DTT) and $20 \mu \mathrm{L}$ of $0.1 \mathrm{mM} \mathrm{ATP}-50 \mathrm{mM} \mathrm{MgCl}$ were added for $1 \mathrm{~h}$. Positive and negative controls were included in each plate by incubation of enzyme with or without ATP- $\mathrm{MgCl}_{2}$. At the end of incubation, liquid was aspirated, and plates were washed three times with wash buffer. A $75 \mu \mathrm{L}$ (400 ng) sample of europium labeled anti-phosphotyrosine antibody was added to each well for another $1 \mathrm{~h}$ of incubation. After washing, enhancement solution was added and the signal was detected by Victor (Wallac Inc., Gaithersburg, MD, USA) with excitation at $340 \mathrm{~nm}$ and emission at $615 \mathrm{~nm}$. The percentage of auto-phosphorylation inhibition by the compounds was calculated using the following formula: $100 \%-$ [(negative control)/(positive control - negative control) $]$. The $\mathrm{IC}_{50}$ was obtained from curves of percentage inhibition with eight concentrations of compound. As the contaminants in the enzyme preparation are fairly low, the majority of the signal detected by the anti-phosphotyrosine antibody is from EGFR. 


\subsection{Evaluation of the in Vivo Antitumor Activities}

\subsubsection{Animals and Cell Lines}

Kunming mice (SPF, male or female, $20 \pm 2 \mathrm{~g}$ ) were purchased from the experimental animal center of China Pharmaceutical University. Animals were housed in a temperature $\left(22 \pm 2{ }^{\circ} \mathrm{C}\right)$ and relatively humidity (50\%)-controlled room on a $12 \mathrm{~h}$ light/dark cycle, given free access to food and water, and acclimatized for at least one week prior to use. All the animal experiments were performed in accordance with the Regulations of the Experimental Animal Administration issued by the State Committee of Science and Technology of China.

Cell lines used for evaluation of the in vivo antitumor activity in this study included three tumor cell lines, namely S180 (sarcoma tumer cell line), HepG2 (liver carcinoma cell line), EAC (Ehrlich ascites carcinoma cell line). All of cell lines were purchased by the Shanghai Institutes for Biological Sciences, Chinese Academy of Sciences, and the cells were cultured in RPMI-1640 medium, which was supplemented with $10 \%$ heat-inactivated fetal bovine serum, $100 \mathrm{U} / \mathrm{mL}$ penicillin and $100 \mathrm{U} / \mathrm{mL}$ streptomycin and cultured in an atmosphere of $5 \% \mathrm{CO}_{2}$ at $37{ }^{\circ} \mathrm{C}$. Cells were collected for the experiments in the logarithmic growth phase.

To establish the tumor-bearing mouse model, the cell lines were harvested and inoculated subcutaneously into the right armpit region of the mice. On the 7 th day, the tumor ascrites were obtained and washed with sterile PBS. Under sterile condition, the tumor ascrites were diluted with sterile nomal saline to $1 \times 10^{10} / \mathrm{L}$ cell suspension. Tumor ascites were maintained in vivo in mice by transplantation of $0.2 \mathrm{~mL}$ of ascites $\left(2 \times 10^{6}\right.$ cells $)$ from the infected mice to the non-infected mice.

\subsubsection{In Vivo Tumor Xenograft Model}

Each Kunming mouse (male or female, weight $20 \pm 2 \mathrm{~g}$ ) were inoculated with seven-day-old ascrite $\left(0.2 \mathrm{~mL}, 2 \times 10^{6}\right.$ cells $)$ subcutaneously into the right front armpit. $24 \mathrm{~h}$ after implantation of tumor cells, the mice were randomly divided into five test groups with 10 mice per group. Each mouse was weighed immediately after inoculation. The mice were treated by oral gavage with test samples $(60 \mathrm{mg} / \mathrm{kg} / \mathrm{day})$ or normal saline (NS, $10 \mathrm{~mL} / \mathrm{kg}$ ) for ten days once daily. On day 11, the mice were sacrificed via cervical dislocation, and the mouse and tumor were excised and weighed for evaluating the tumor growth inhibition. The tumor inhibitory rate was calculated by the following formula:

$$
\text { Tumor inhibitory rate rate }(\%)=\left(\frac{W_{\text {control }}-W_{\text {treated }}}{W_{\text {control }}}\right) \times 100 \%
$$

where $\mathrm{W}_{\text {control }}$ and $\mathrm{W}_{\text {treated }}$ were the average tumor weights of the control and treated mice, respectively. EAC tumor-bearing mice were observed for mean survival time. The effect of glycyrrhizin analogs on percentage increases in life span was calculated on the basis of mortality of the experimental mice:

$$
\begin{gathered}
\text { Mean survival time }=\frac{\sum \text { Survival time (days) of each mouse in a group }}{\text { Total number of mice }} \\
\% \text { ILS }=\frac{\text { MST of treated group }}{\text { MST of control group }} \times 100
\end{gathered}
$$




\section{Conclusions}

In summary, we synthesized glycyrrhizin analogs by glucuronidase biotransformation and alkaline isomerization, and evaluated their biological activities in vitro and in vivo. Anticancer activities of monoglucuronide GAMGs were higher than those of bisglucuronide GAs, while 1the $8 \alpha$-epimer showed better activity than the $18 \beta$-epimer. Among them, $18 \alpha$-GAMG displayed the most potent in vitro activity, with $\mathrm{IC}_{50}$ values of $6.67,7.43$ and $15.76 \mu \mathrm{M}$ against $\mathrm{HepG} 2$, Hela and $\mathrm{A} 549$, and in vivo activity with inhibitory rates $39.8 \%$ and $49.7 \%$ for S180 and HepG2 tumor-bearing mice, respectively, and it significantly enhanced the survival rate of EAC tumor-bearing mice to $45.4 \%$. The docking calculations showed that four analogs had better binding affinity to EGFR than the reference compound erlotinib and their binding energy had the same trend as anticancer activities, which further proved the correlation between anticancer activities and EGFR inhibitory activities of these compounds. In the binding model, high active compound $18 \alpha$-GAMG was nicely bound to EGFR via six hydrogen bonds with ASP831, GLU738, THR766 (three bonds), LYS721 and one charge interaction, leading to the increased anticancer activities of $18 \alpha$-GAMG. Therefore, $18 \alpha$-GAMG is of interest for further studies as a potential anticancer agent. Further structural optimization of $18 \alpha$-GAMG is ongoing using a variety of rational design strategies [33].

\section{Supplementary Materials}

Supplementary materials can be accessed at: http://www.mdpi.com/1420-3049/19/5/6368/s1.

\section{Acknowledgments}

The authors wish to thank the National Natural Science Foundation of China (Nos. 21272008, 20802003), Science and Technological Fund of Anhui Province for Outstanding Youth (1408085J04).

\section{Author Contributions}

YongAn Yang and HaiLiang Zhu designed research; YongAn Yang, WenJian Tang, Xin Zhang, JiWen Yuan and XinHua Liu performed research and analyzed the data; YongAn Yang and WenJian Tang wrote the paper. All authors read and approved the final manuscript.

\section{Conflicts of Interest}

The authors declare no conflict of interest.

\section{References}

1. Citri, A.; Yarden, Y. EGF-ERBB signaling: Towards the systems level. Nat. Rev. Mol. Cell Biol. 2006, 7, 505-516.

2. Mendelsohn, J. Targeting the epidermal growth factor receptor for cancer therapy. J. Clin. Oncol. 2002, 20, 1S-13S.

3. Zandi, R.; Larsen, A.B.; Andersen, P.; Stockhausen, M.T.; Poulsen, H.S. Mechanisms for oncogenic activation of the epidermal growth factor receptor. Cell Signal. 2007, 19, 2013-2023. 
4. Berasain, C.; Castillo, J.; Prieto, J.; Avila, M.A. New molecular targets for hepatocellular carcinoma: The ErbB1 signaling system. Liver Int. 2007, 27, 174-185.

5. Berasain, C.; Ujue, L.M.; Urtasun, R.; Goñi, S.; Elizalde, M.; Garcia-Irigoyen, O.; Azcona, M.; Prieto, J.; Avila, M.A. Epidermal growth factor receptor (EGFR) crosstalks in liver cancer. Cancers 2011, 3, 2444-2461.

6. Natarajan, A.; Wagner, B.; Sibilia, M. The EGF receptor is required for efficient liver regeneration. Proc. Natl. Acad. Sci. USA 2007, 104, 17081-17086.

7. Mitchell, C.; Nivison, M.; Jackson, L.F.; Fox, R.; Lee, D.C.; Campbell, J.S.; Fausto, N. Heparin-binding epidermal growth factor-like growth factor links hepatocyte priming with cell cycle progression during liver regeneration. J. Biol. Chem. 2005, 280, 2562-2568.

8. Hopfner, M.; Sutter, A.P.; Huether, A.; Schuppan, D.; Zeitz, M.; Scherubl, H. Targeting the epidermal growth factor receptor by gefitinib for treatment of hepatocellular carcinoma. J. Hepatol. 2004, 41, 1008-1016.

9. Huether, A.; Hopfner, M.; Sutter, A.P.; Schuppan, D.; Scherubl, H. Erlotinib induces cell cycle arrest and apoptosis in hepatocellular cancer cells and enhances chemosensitivity towards cytostatics. J. Hepatol. 2005, 43, 661-669.

10. Newman, D.J.; Cragg, G.M. Natural products as sources of new drugs over the 30 years from 1981-2010. J. Nat. Prod. 2012, 75, 311-335.

11. Baltina, L.A. Chemical modification of glycyrrhizic acid as a route to new bioactive compounds for medicine. Curr. Med. Chem. 2003, 10, 155-171.

12. Morgan, A.G.; McAdam, W.A. Glycyrrhiza glabra. (Monograph). Altern. Med. Rev. 2005, 10, 230-237.

13. Asl, M.N.; Hosseinzadeh, H. Review of pharmacological effects of Glycyrrhiza sp. and its bioactive compounds. Phytother. Res. 2008, 22, 709-724.

14. Van Rossum, T.G.; Vulto, A.G.; de Man, R.A.; Brouwer, J.T.; Schalm, S.W. Glycyrrhizin as a potential treatment for chronic hepatitis C. Aliment Pharmacol. Ther. 1998, 12, 199-205.

15. Arase, Y.; Ikeda, K.; Murashima, N.; Chayama, K.; Tsubota, A.; Koida, I.; Suzuki, Y.; Saitoh, S.; Kobayashi, M.; Kumada, H. The long-term efficacy of glycyrrhizin in chronic hepatitis C patients. Cancer 1997, 79, 1494-1500.

16. Chayama, K. Management of chronic hepatitis $\mathrm{C}$ and prevention of hepatocellular carcinoma. J. Gastroenterol. 2002, 37, 69-73.

17. Van Rossum, T.G.; Vulto, A.G.; Hop, W.C.; Schalm, S.W. Glycyrrhizin-induced reduction of ALT in European patients with chronic hepatitis C. Am. J. Gastroenterol. 2001, 96, 2432-2437.

18. Thirugnanam, S.; Xu, L.; Ramaswamy, K.; Gnanasekar, M. Glycyrrhizin induces apoptosis in prostate cancer cell lines DU-145 and LNCaP. Oncol. Rep. 2008, 20, 1387-1392.

19. Tripathi, M.; Singh, B.K.; Kakkar, P. Glycyrrhizic acid modulates t-BHP induced apoptosis in primary rat hepatocytes. Food Chem. Toxicol. 2009, 47, 339-347.

20. Kim, K.J.; Choi, J.S.; Kim, K.W.; Jeong, J.W. The anti-angiogenic activities of glycyrrhizic acid in tumor progression. Phytother. Res. 2013, 27, 841-846.

21. Feng, S.; Li, C.; Xu, X.; Wang, X. Screening strains for directed biosynthesis of $\beta$-D-mono-glucuronide-glycyrrhizin and kinetics of enzyme production. J. Mol. Catal. B: Enzym. 2006, 43, 63-67. 
22. Lu, L.; Zhao, Y.; Yu, H.S.; Huang, H.Z.; Kang, L.P.; Cao, M.; Cui, J.M.; Yu, L.Y.; Song, X.B.; Ma, B.P. Preparation of glycyrrhetinic acid monoglucuronide by selective hydrolysis of glycyrrhizic acid via biotransformation. Chin. Herb. Med. 2012, 4, 324-328.

23. Mizutani, K.; Kambara, T.; Masuda, H.; Tamura, Y.; Ikeda, T.; Tanak, O.; Tokuda, H.; Nishino, H.; Kozuka, M.; Konoshima, T.; et al. Glycyrrhetic acid monoglucuronide (MGGR): Biological activities. Int. Congr. Ser. 1998, 1157, 225-235.

24. Park, H.Y.; Park, S.H.; Yoon, H.K.; Han, M.J.; Kim, D.H. Anti-allergic activity of 18 $\alpha$-glycyrrhetinic acid-3-O- $\alpha$-D-glucuronide. Arch. Pharm. Res. 2004, 27, 57-60.

25. Baltina, L.A.; Stolyarova, O.V.; Baltina, L.A.; Kondratenko, R.M.; Plyasunova, O.A.; Pokrovskii, A.G. Synthesis and antiviral activity of $18 \alpha$-glycyrrhizic acid and its esters. Pharm. Chem. J. 2010, 44, 299-302.

26. Shetty, A.V.; Thirugnanam, S.; Dakshinamoorthy, G.; Samykutty, A.; Zheng, G.; Chen, A.; Bosland, M.C.; Kajdacsy-Balla, A.; Gnanasekar, M. 18 $\alpha$-glycyrrhetinic acid targets prostate cancer cells by down-regulating inflammation-related genes. Int. J. Oncol. 2011, 39, 635-640.

27. Qu, Y.; Chen, W.H.; Zong, L.; Xu, M.Y.; Lu, L.G. 18 $\alpha$-Glycyrrhizin induces apoptosis and suppresses activation of rat hepatic stellate cells. Med. Sci. Monit. 2012, 18, BR24-32.

28. Kimura, M.; Inoue, H.; Hirabayashi, K.; Natsume, H.; Ogihara, M. Glycyrrhizin and some analogues induce growth of primary cultured adult rat hepatocytes via epidermal growth factor receptors. Eur. J. Pharmacol. 2001, 431, 151-161.

29. Tsou, H.R.; Mamuya, N.; Johnson, B.D.; Reich, M.F.; Gruber, B.C.; Ye, F.; Nilakantan, R.; Shen, R.; Discafani, C.; DeBlanc, R.; et al. 6-Substituted-4-(3-bromophenylamino)quinazolines as putative irreversible inhibitors of the epidermal growth factor receptor (EGFR) and human epidermal growth factor receptor (HER-2) tyrosine kinases with enhanced antitumor activity. J. Med. Chem. 2001, 44, 2719-2734.

30. Li, W.; Sha, Y.; Chen, L.X.; Qiu, F.; Wu, L.J. NMR data assignments of two 18-epimers of diammonium glycyrrhizinate. J. Shenyang Pharm. Univ. 2005, 7, 273-278.

31. Mollica, L.; Marchis, F.D.; Spitaleri, A.; Dallacosta, C.; Pennacchini, D.; Zamai, M.; Agresti, A.; Trisciuoglio, L.; Musco, G.; Bianchi, M.E. Glycyrrhizin binds to high-mobility group box 1 protein and inhibits its cytokine activities. Chem. Biol. 2007, 14, 431-441.

32. Du, D.; Yan, J.; Ren, J.H.; Lv, H.; Li, Y.; Xu, S.; Wang, Y.D.; Ma, S.G.; Qu, J.; Tang, W.B.; et al. Synthesis, biological evaluation, and molecular modeling of glycyrrhizin derivatives as potent high-mobility group box-1 inhibitors with anti-heart-failure activity in vivo. J. Med. Chem. 2013, 56, 97-108.

33. Huggins, J.D.; Sherman, W.; Tidor, B. Rational approaches to improving selectivity in drug design. J. Med. Chem. 2012, 55, 1424-1444.

Sample Availability: Samples of the four compounds are available from the authors.

(C) 2014 by the authors; licensee MDPI, Basel, Switzerland. This article is an open access article distributed under the terms and conditions of the Creative Commons Attribution license (http://creativecommons.org/licenses/by/3.0/). 